\title{
Purification and characterization of recombinant human farnesyl diphosphate synthase expressed in Escherichia coli
}

\author{
Victor D.-H. DING, ${ }^{*} \dagger$ Bradley T. SHEARES, ${ }^{*}$ James D. BERGSTROM, ${ }^{*}$ Mitree M. PONPIPOM, $\ddagger$ \\ Lawrence B. PEREZ§ and C. Dale POULTER \\ *Department of Biochemical Regulation and $\ddagger$ Department of Medicinal Chemical Research, \\ Merck Sharp \& Dohme Research Laboratories, Rahway, NJ 07065, U.S.A., and §Department of Chemistry, University of Utah, \\ Salt Lake City, UT 84112, U.S.A.
}

\begin{abstract}
We previously reported the isolation of a partial-length human fetal-liver cDNA encoding farnesyl diphosphate (FPP) synthase (EC 2.5.1.10) and the expression of an active FPP synthase fusion protein in Escherichia coli. The expressed human FPP synthase fusion protein has now been purified to apparent homogeneity by using two chromatographic steps. The purification scheme allowed the preparation of $1.8 \mathrm{mg}$ of homogeneous protein from $149 \mathrm{mg}$ of crude extract in a $64 \%$ yield with a 52-fold enrichment. A single band with a subunit molecular mass of $39 \mathrm{kDa}$ was observed by Coomassie Blue staining after SDS/PAGE. A molecular mass of $78-80 \mathrm{kDa}$ was calculated for the native form of the fusion protein by h.p.l.c. on a SEC-250 column, suggesting that the active fusion protein is a dimer. The purified fusion protein has FPP synthase condensation activities in the presence of both substrates, isopentenyl diphosphate and geranyl diphosphate. Enzyme activity was inhibited by a bisubstrate analogue of isopentenyl diphosphate and dimethylallyl diphosphate, and a small amount of higher prenyltransferase was observed. Michaelis constants for isopentenyl diphosphate and geranyl diphosphate were 0.55 and $0.43 \mu \mathrm{M}$ respectively, and $V_{\max }$ for synthesis of farnesyl diphosphate from these substrates was $1.08 \mu \mathrm{mol} / \mathrm{min}$ per $\mathrm{mg}$. These results suggest that the structure and catalytic properties of the expressed FPP synthase fusion protein are virtually identical with those of the native human liver enzyme.
\end{abstract}

\section{INTRODUCTION}

Prenyltransferases are a large group of biosynthetic enzymes found in both animals and plants. They catalyse the sequential condensation of electron-rich acceptors with allylic diphosphates. Farnesyl diphosphate (FPP) synthase (EC 2.5.1.10), a cytosolic prenyltransferase involved in the synthesis of sterols, catalyses the sequential 1'-4 condensation of isopentenyl diphosphate (IPP) with dimethylallyl diphosphate (DMAPP) and geranyl diphosphate (GPP) to yield FPP (Poulter \& Rilling, 1978, 1981; Poulter et al., 1979). FPP synthase has been purified from many sources, including micro-organisms (Eberhardt \& Rilling, 1975; Sagami et al., 1978; Ishii et al., 1986), plants (Green \& West, 1974; Ogura et al., 1985; Light \& Dennis, 1989) and liver tissue of chickens (Reed \& Rilling, 1975), pigs (Holloway \& Popják, 1967), humans (Barnard \& Popják, 1981) and rats (V. D.-H. Ding, unpublished work).

A microsomal cis-prenyltransferase is involved in dolichol phosphate biosynthesis (Wong \& Lennarz, 1982; Adair \& Cafmeyer, 1987), catalysing the addition of isoprene units from IPP to a FPP primer (McGrath, 1977). A mitochondrial transprenyltransferase catalyses the biosynthesis of polyisoprenyl side chains of ubiquinone (Momose \& Rudney, 1972; Trumpower et al., 1974), the electron carrier in the electron-transport chain of mitochondria. These enzymes have not been purified or fully characterized for comparison with FPP synthase. Other nonsterol products of the isoprenoid-biosynthetic pathway include the haem prosthetic group of cytochromes $a$ and $a_{3}$, which contain a farnesyl moiety (Poulter \& Rilling, 1981), prenylated tRNAs (Faust et al., 1980) and prenylated proteins (Schafer et al., 1989; Hancock et al., 1989; Rilling et al., 1989).

FPP synthase is one of the important enzymes in the cholesterol-biosynthesis pathway. The eukaryotic enzyme is a dimer that catalyses two distinct condensation reactions (Rilling, 1985) at a single catalytic site per subunit (Poulter \& Rilling, 1978). The final product, FPP, lies at a multiple branch-point in the isoprene pathway and is an intermediate in the synthesis of sterols, dolichol, ubiquinone and other isoprenylated metabolites. Recently, we isolated a partial-length cDNA-encoding FPP synthase (hpt807) from a human fetal-liver cDNA library (Sheares et al., 1989). Comparison of this cDNA with rat cDNA (Clarke et al., 1987) suggests that hpt807 is about 20 bp short of encoding the initiator methionine of FPP synthase. The human cDNA was expressed as an active fusion protein containing the initiator methionine and six amino acid residues of $\beta$-galactosidase followed in frame by 346 amino acids of human FPP synthase (Sheares et al., 1989). Since the human liver enzyme is not available in the quantities needed for mechanistic, structural and inhibitor studies, we decided to develop a purification method for the recombinant FPP synthase fusion protein. We now describe a procedure for purification of the FPP synthase fusion protein to homogeneity and demonstrate that the catalytic properties of this fusion protein are similar to those of the human liver FPP synthase.

\section{MATERIALS AND METHODS}

\section{Materials}

The following materials were obtained from the source indicated. $\left[4-{ }^{14} \mathrm{C}\right] \mathrm{IPP}(47.9 \mathrm{Ci} / \mathrm{mol})$ was obtained from NEN DuPont, Wilmington, DE, U.S.A. $\mathrm{NaCl}, \mathrm{HCl}$, methanol, chloroform and $\mathrm{Na}_{2} \mathrm{SO}_{4}$ were from EM Sciences, Cherry Hill, NJ, U.S.A. KF, $\mathrm{MgCl}_{2}$, sodium potassium tartrate and ligorine [light petroleum (b.p. $90-110^{\circ} \mathrm{C}$ )] were from Fisher Scientific, Pittsburgh, PA, U.S.A. Dithiothreitol and Tris were from BRL, Bethesda, MD, U.S.A. Isopropyl $\beta$-D-thiogalactopyranoside,

Abbreviations used: FPP, farnesyl diphosphate; IPP, isopentenyl diphosphate; GPP, geranyl diphosphate; DMAPP, dimethylallyl diphosphate.

$\dagger$ To whom all correspondence should be addressed. 
Triton X-100, SDS and ampicillin were from Sigma. LB broth was from Difco, Detroit, MI, U.S.A. Polyacrylamide, bisacrylamide, $N N N^{\prime} N$ '-tetramethylethylenediamine ('TEMED'), ammonium persulphate, Coomassie Blue and protein standards were from Bio-Rad, Richmond, CA, U.S.A. IPP and GPP were synthesized in M.M.P.'s laboratory.

H.p.l.c. pumps (type 364), an h.p.l.c. programmer 50 and a variable-wavelength detector were from Knauer Sonntek, Woodcliff Lake, NJ, U.S.A. An injector (Waters, model U6K) was from Millipore Corp., Milford, MA, U.S.A. Chromatography software (Turbochrome) and an interface (900 series) were from PE Nelson, Norwalk, CT, U.S.A.

\section{Preparation of S-100 supernatant}

First, $25 \mathrm{ml}$ of an overnight culture of DH $5 \alpha$ FIQ transformed cells were inoculated into $500 \mathrm{ml}$ of LB broth containing $0.1 \mathrm{mg}$ of ampicillin $/ \mathrm{ml}$ and grown for approx. $2.5 \mathrm{~h}$ at $37^{\circ} \mathrm{C}$. When the cultures reached an $A_{660}$ of 0.7 , isopropyl thiogalactoside was added to a final concentration of $1 \mathrm{~mm}$. After an additional $4 \mathrm{~h}$ of growth, the cells were harvested and washed with phosphatebuffered saline (Sheares et al., 1989), pH 7.4. The pellet was resuspended in $15 \mathrm{ml}$ of phosphate-buffered saline, and the cells were disrupted in a French press $(12.4 \mathrm{MPa})$. The cell extract was subjected to low-speed centrifugation to remove unbroken cells and cell debris, followed by centrifugation at $100000 \mathrm{~g}$ for $1 \mathrm{~h}$. The S-100 supernatant was collected and used for subsequent analyses and enzyme purification.

\section{Purification of human FPP synthase fusion protein}

First, $10 \mathrm{ml}$ of the $\mathrm{S}-100$ supernatant was diluted with an equal volume (protein concentration over $20 \mathrm{mg} / \mathrm{ml}$ ) of Tris $/ \mathrm{HCl}$ buffer (20 mM, pH 7.2). Satd. $\left(\mathrm{NH}_{4}\right)_{2} \mathrm{SO}_{4}$ was added to $28 \%$ saturation, and the solution was stirred for $5 \mathrm{~min}$ at $4{ }^{\circ} \mathrm{C}$. The mixture was centrifuged at $8000 \mathrm{~g}$ for $10 \mathrm{~min}$. The supernatant was then adjusted to $50 \%$ saturation of $\left(\mathrm{NH}_{4}\right)_{2} \mathrm{SO}_{4}$ and centrifuged at $13000 \mathrm{~g}$ for $20 \mathrm{~min}$. The resulting pellet was dissolved in $5 \mathrm{ml}$ of Tris/ $\mathrm{HCl}$ buffer and dialysed extensively against the same buffer. The dialysis residue was centrifuged at $13000 \mathrm{~g}$ for $30 \mathrm{~min}$, and $8-10 \mathrm{mg}$ of soluble protein was loaded on an h.p.l.c. DEAE-cellulose ion-exchange column (Bio-Gel TSK DEAE-5-PW, $150 \mathrm{~mm} \times 21.5 \mathrm{~mm}$; Bio-Rad) that had been pre-equilibrated in the Tris/ $\mathrm{HCl}$ buffer. The column was washed for $40 \mathrm{~min}$ at a flow rate of $4 \mathrm{ml} / \mathrm{min}$ before elution with a linear $\mathrm{NaCl}$ gradient $(0.09-0.3 \mathrm{M})$ in $20 \mathrm{~mm}$-Tris/ $\mathrm{HCl}$ buffer. Fractions of volume $4 \mathrm{ml}$ were collected over $50 \mathrm{~min}$; those containing enzyme activity (see Fig. 1) were pooled, concentrated on an Amicon concentrator (PM 30 membrane) and then dialysed extensively against $10 \mathrm{mM}$-Tris $/ \mathrm{HCl}$ buffer $(\mathrm{pH} \mathrm{7.2)}$. The protein recovered from dialysis was centrifuged at $13000 \mathrm{~g}$ for $30 \mathrm{~min}$ and applied to an h.p.l.c. hydroxyapatite column (Bio-Gel HPHT, $100 \mathrm{~mm} \times 7.8 \mathrm{~mm}$; Bio-Rad) which was pre-equilibrated with $10 \mathrm{mM}$-Tris/ $\mathrm{HCl}$ buffer. After the column had been washed for $40 \mathrm{~min}$ at a flow rate of $1 \mathrm{ml} / \mathrm{min}$, the bound proteins were eluted with a linear sodium phosphate buffer ( $\mathrm{pH}$ 6.8) gradient $(0.07-0.3 \mathrm{M})$ over $50 \mathrm{~min}$. Fractions of volume $1 \mathrm{ml}$ were collected (see Fig. 2) and those fractions containing FPP synthase activity were pooled, concentrated and stored at $-80^{\circ} \mathrm{C}$ in solutions containing $30 \%$ glycerol.

\section{Determination of protein concentration}

Protein concentrations were determined by the method of Lowry et al. (1951), with BSA as a standard.

\section{Enzyme activity assay}

FPP synthase activity was measured by a modification of the method described by Reed \& Rilling (1975). The assay mixture contained $20 \mathrm{~mm}$ Tris/ $\mathrm{HCl}$ buffer (pH 7.6), $1 \mathrm{~mm}-\mathrm{MgCl}_{2}, 1 \mathrm{~mm}$ dithiothreitol, $100 \mu \mathrm{M}-\mathrm{GPP}$ and $80 \mu \mathrm{M}-\left[4-{ }^{14} \mathrm{C}\right] \mathrm{IPP}$ (sp. radioactivity $9.3 \mathrm{Ci} / \mathrm{mol}$ ) in a total volume of $50 \mu$ l. After the addition of enzyme (approx. $3 \mu \mathrm{l}$ ), the reaction mixture was incubated for $10 \mathrm{~min}$ at $37^{\circ} \mathrm{C}$ and the reaction was terminated by addition of $0.5 \mathrm{ml}$ of a satd. $\mathrm{NaCl}$ solution. The radiolabelled FPP was extracted with $0.5 \mathrm{ml}$ of butan-1-ol. After thorough mixing and brief centrifugation, $0.25 \mathrm{ml}$ of the alcohol phase was removed and counted for radioactivity in a Beckman scintillation spectrometer. For inhibition experiments with 3-methyl-6-methyleneoct-2-ene-1,8-diyl bis-diphosphate, the concentrations of both substrates were $1 \mu \mathrm{M}$ and the specific radioactivity of $\left[{ }^{14} \mathrm{C}\right] \mathrm{IPP}$ was $47.9 \mathrm{Ci} / \mathrm{mol}$; an equal activity of both enzymes was used in all assays.

Microsomal prenyltransferase activity was measured by a modification of the procedure described by Adair \& Cafmeyer (1987) and Adair et al. (1984). The reaction mixture contained $50 \mathrm{mM}$-sodium phosphate buffer (pH 7.4), $150 \mu \mathrm{M}-\mathrm{FPP}, 2 \mathrm{mM}-$ $\mathrm{MgCl}_{2}, 1 \mathrm{~mm}$-dithiothreitol, $150 \mathrm{~mm}-\mathrm{NaCl}, 3 \mathrm{~mm}-\mathrm{KF}, 0.5 \mu \mathrm{Ci}$ of $\left[{ }^{14} \mathrm{C}\right] \mathrm{IPP}, 2 \%$ Triton $\mathrm{X}-100$ and $200 \mu \mathrm{g}$ of protein, in a total assay volume of $0.5 \mathrm{ml}$. After incubation for $1 \mathrm{~h}$ at $37^{\circ} \mathrm{C}$, the samples were processed as described previously (Adair \& Cafmeyer, 1987). In this assay, rat liver microsomal fractions were used as positive control. Liver microsomal fractions were prepared as previously described (Coon et al., 1978).

\section{Molecular-mass determination}

The molecular mass of the native protein was determined by h.p.l.c. size-exclusion column chromatography (Bil-Sil SEC-250; Bio-Rad; $300 \mathrm{~mm} \times 7.5 \mathrm{~mm}$ ). Chromatography was carried out in $0.1 \mathrm{M}-\mathrm{Na}_{2} \mathrm{SO}_{4} / 0.1 \mathrm{~m}$-sodium phosphate buffer $(\mathrm{pH} 7.0)$ at a flow rate of $1 \mathrm{ml} / \mathrm{min}$.

SDS/PAGE was used to determine the molecular mass of the protein under reducing conditions (Laemmli, 1970; Swank \& Munkres, 1971). Protein standards used for calibration were phosphorylase $b(94000 \mathrm{Da})$, albumin $(68000 \mathrm{Da})$, ovalbumin (45000 Da), carbonic anhydrase (30000 Da) and trypsin inhibitor $(21000 \mathrm{Da})$. The $R_{F}$ for each protein was determined from duplicate samples, and the molecular mass of the recombinant fusion protein was estimated from a standard calibration curve.

\section{Enzyme kinetics}

For kinetic analyses, the radioactivity of acid-labile products in the reaction mixture was measured as described by Rilling (1985). Each assay mixture contained $20 \mathrm{~mm}$-Tris/HCl buffer (pH 7.6), $1 \mathrm{~mm}-\mathrm{MgCl}_{2}, 1 \mathrm{~mm}$-dithiothreitol and $5 \mathrm{ng}$ of purified enzyme, in a total volume of $0.25 \mathrm{ml}$. The assays were carried out at $37^{\circ} \mathrm{C}$ for $5 \mathrm{~min}$ with varied substrate concentrations (IPP, 0.4, $0.6,1.0 \mu \mathrm{M}$; GPP, $0.5,1.0,2.0 \mu \mathrm{M}$ ). $\left[4-{ }^{14} \mathrm{C}\right] \mathrm{IPP}$ (sp. radioactivity $47.9 \mathrm{Ci} / \mathrm{mol}$ ) was used. At the end of a $5 \mathrm{~min}$ incubation, $1 \mathrm{ml}$ of methanol $/ \mathrm{HCl}(4: 1, \mathrm{v} / \mathrm{v})$ was added. Incubation was continued for $10 \mathrm{~min}$ at $37^{\circ} \mathrm{C}$, after which the reaction products were extracted with $2 \mathrm{ml}$ of ligorine, and $1 \mathrm{ml}$ of the organic layer was transferred to a scintillation vial for counting of radioactivity.

\section{RESULTS AND DISCUSSION}

\section{Purification of human FPP synthase fusion protein}

The purification of the recombinant FPP synthase fusion protein is summarized in Table 1 . The crude $\mathrm{S}-100$ supernatant was fractionated with satd. $\left(\mathrm{NH}_{4}\right)_{2} \mathrm{SO}_{4}$ before chromatography. The $28 \%$-satd. fraction, containing only $10 \%$ of the total activity, was discarded, and the 28-50\%-satd. fraction, containing $89 \%$ of the total enzyme activity, was resuspended in $20 \mathrm{~mm}$-Tris/ $\mathrm{HCl}, \mathrm{pH} 7.2$, and dialysed against the same buffer. The dialysis residue was clarified by centrifugation and applied 
Table 1. Purification of human FPP synthase fusion protein

\begin{tabular}{lcccccc}
\hline Step & $\begin{array}{c}\text { Volume } \\
(\mathrm{ml})\end{array}$ & $\begin{array}{c}\text { Total } \\
\text { protein } \\
(\mathrm{mg})^{*}\end{array}$ & $\begin{array}{c}\text { Total } \\
\text { activity } \\
(\text { units } \dagger\end{array}$ & $\begin{array}{c}\text { Specific } \\
\text { activity } \\
\text { (units/mg) }\end{array}$ & $\begin{array}{c}\text { Purification } \\
\text { (fold) }\end{array}$ & $\begin{array}{c}\text { Recovery } \\
(\%)\end{array}$ \\
\hline $\begin{array}{l}\text { Crude (S-100) } \\
28-50 \% \text {-satd. }\left(\mathrm{NH}_{4}\right)_{2} \mathrm{SO}_{4}\end{array}$ & 10 & 149 & 22 & 0.15 & 1 & 100 \\
$\begin{array}{l}\text { H.p.l.c.-DEAE-cellulose } \\
\text { ion exchange }\end{array}$ & 6.6 & 57 & 19.5 & 0.34 & 2.3 & 89 \\
H.p.l.c. hydroxyapatite & 2.4 & 3.1 & 16 & 5.2 & 35 & 73 \\
H. & 1.6 & 1.8 & 14 & 7.8 & 52 & 64
\end{tabular}

* Protein was determined by the method of Lowry et al. (1951).

$\dagger$ Units are $\mu \mathrm{mol}$ of FPP produced $/ \mathrm{min}$.

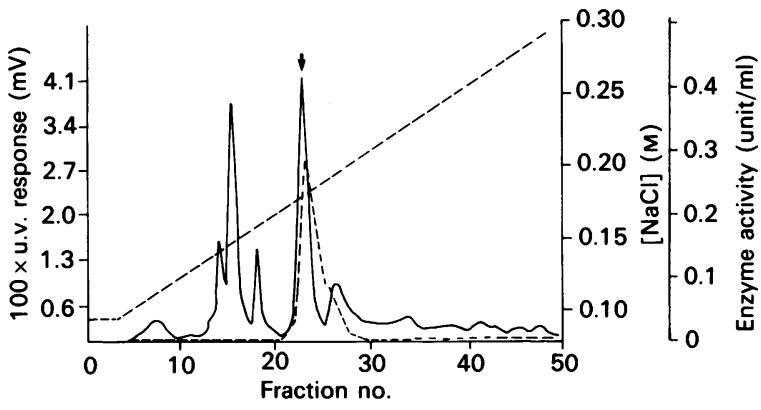

Fig. 1. h.p.l.c. on a DEAE-cellulose ion-exchange column

Protein from the $28-50 \%$-satd.- $\left(\mathrm{NH}_{4}\right)_{2} \mathrm{SO}_{4}$ fraction $(8-10 \mathrm{mg})$ was loaded on a Bio-Rad h.p.l.c. DEAE-cellulose column. The column was washed with $20 \mathrm{mM}-\mathrm{Tris} / \mathrm{HCl}(\mathrm{pH} 7.2)$, and the bound proteins were eluted with a linear $\mathrm{NaCl}$ gradient $(0.09-0.3 \mathrm{M})$, and $4 \mathrm{ml}$ fractions were collected. The continuous line indicates u.v. absorbance $\left(A_{280}\right)$ of protein eluted from the column; the broken line indicates FPP synthase enzyme activity in units/ml (units are $\mu \mathrm{mol}$ of FPP produced $/ \mathrm{min}$ ); the broken straight line indicates the concentration of the $\mathrm{NaCl}$ gradient. The arrow indicates the peak of FPP synthase fusion protein.

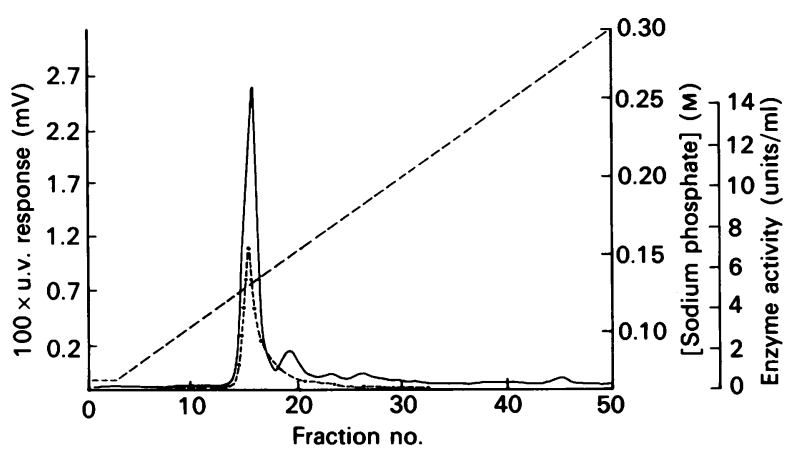

Fig. 2. Chromatography of crude FPP synthetase fusion protein on hydroxyapatite

Crude FPP synthetase fusion protein obtained after DEAE-cellulose chromatography (3-5 mg) was loaded on an h.p.l.c. hydroxyapatite column. The column was washed with $10 \mathrm{~mm}$-Tris/HCl buffer $(\mathrm{pH} 7.2)$, and the bound proteins were eluted with a linear sodium phosphate gradient $(0.07-0.3 \mathrm{M})$; fractions of volume $1 \mathrm{ml}$ were collected. The continuous line indicates the u.v. absorbance $\left(A_{280}\right)$ of protein eluted from the column; the broken line $(\bullet-\cdots)$ indicates FPP synthase enzyme activity; the broken straight line indicates the concentration of sodium phosphate.

to an h.p.l.c. DEAE-cellulose ion-exchange column. Fig. 1 shows the elution profile from a DEAE-cellulose h.p.l.c. column. FPP synthase activity was eluted at approx. $0.17 \mathrm{M}-\mathrm{NaCl}$. This was the most significant step, giving a 15 -fold purification and $82 \%$

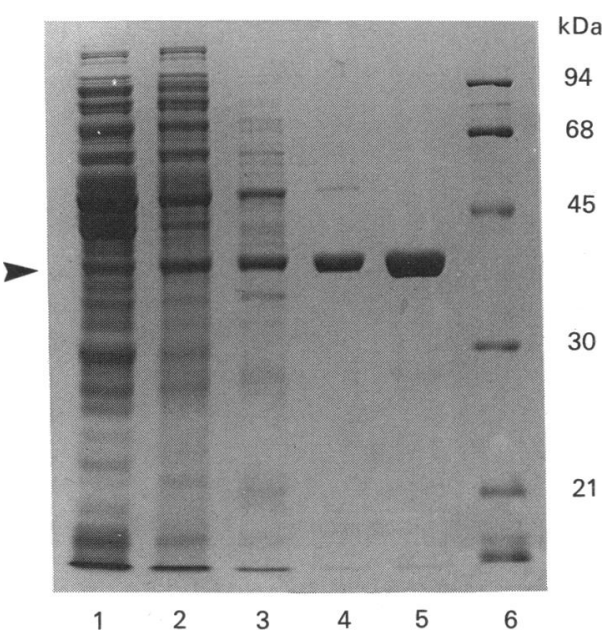

Fig. 3. Purification of human FPP synthase fusion protein as monitored by SDS/PAGE

Proteins after each purification step in Table 1 were electrophoresed on a $10 \%$ polyacrylamide gel. Lane $1, \mathrm{~S}-100$ supernatant, $45 \mu \mathrm{g}$ of protein; lane $2,28-50 \%$-satd.-( $\left(\mathrm{NH}_{4}\right)_{2} \mathrm{SO}_{4}$ fraction, $45 \mu \mathrm{g}$ of protein; lane 3, protein from DEAE-cellulose chromatography without prior $\left(\mathrm{NH}_{4}\right)_{2} \mathrm{SO}_{4}$ fractionation, $20 \mu \mathrm{g}$ of protein ; lane 4, protein from DEAE-cellulose chromatography with prior $\left(\mathrm{NH}_{4}\right)_{2} \mathrm{SO}_{4}$ fractionation, $15 \mu \mathrm{g}$ of protein; lane 5, after hydroxyapatite chromatography, $25 \mu \mathrm{g}$ of protein; lane 6, molecular-mass markers (see the Materials and methods section). The arrowhead indicates the location of FPP synthase fusion protein. The gel was stained with Coomassie Blue.

recovery of enzyme activity. The purity of the fusion protein was greater than $90 \%$ as judged by SDS/PAGE (Fig. 3, lane 4). Although less than $40 \%$ of total protein was removed by $\left(\mathrm{NH}_{4}\right)_{2} \mathrm{SO}_{4}$ precipitations, the step was essential, since DEAEcellulose of crude, unfractionated extract gave significant levels of contamination in the fusion-protein fraction (Fig. 3, lane 3).

After DEAE-cellulose h.p.l.c., the combined fractions containing fusion protein $(3-5 \mathrm{mg}$ ) were diluted in $10 \mathrm{~mm}-\mathrm{Tris} / \mathrm{HCl}$ buffer (pH 7.2) and loaded on an h.p.l.c. hydroxyapatite column. The peak of enzyme activity was eluted at approx. $0.12 \mathrm{M}$-sodium phosphate (see Fig. 2), and the pooled fractions of this peak showed a single band on SDS/PAGE (Fig. 3, lane 5). Thus the 52-fold purification of the recombinant human FPP synthase fusion protein to apparent homogeneity was accomplished in four steps, yielding $1.8 \mathrm{mg}$ of homogeneous fusion protein obtained from $149 \mathrm{mg}$ of the S-100 fraction with an overall recovery of $64 \%$. This procedure is reproducible for purification of large quantities of FPP synthase fusion protein. The homogeneous protein was relatively stable at $4{ }^{\circ} \mathrm{C}$ in $\mathrm{Tris} / \mathrm{HCl}$ buffer. We encountered an approx. $10 \%$ loss of enzyme activity within 2 weeks. 


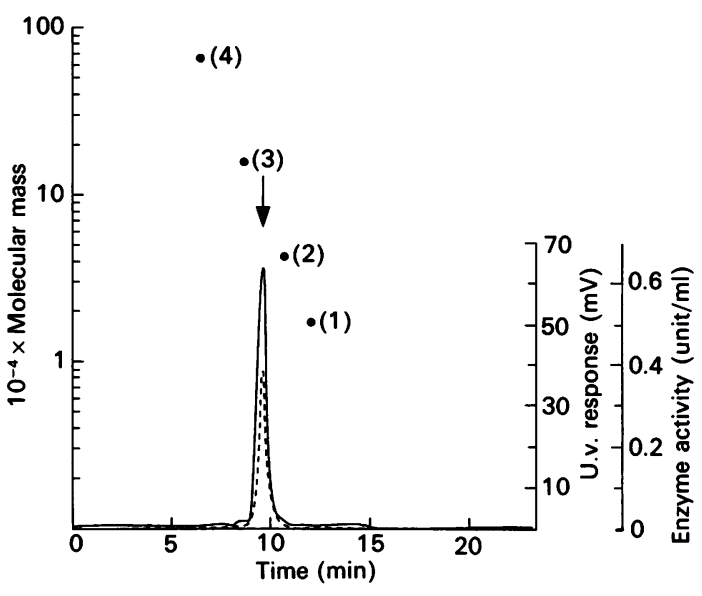

Fig. 4. H.p.l.c. gel-filtration profile of FPP synthase fusion protein

Homogeneous FPP synthase fusion protein ( $40 \mu \mathrm{g}$ of protein) was chromatographed on a Bio-Sil SEC-250 column pre-equilibrated with $0.1 \mathrm{M}$-sodium phosphate and $0.1 \mathrm{M}-\mathrm{Na}_{2} \mathrm{SO}_{4}(\mathrm{pH} 7.0)$. Fractions of volume $1 \mathrm{ml}$ were collected and assayed for FPP synthase. The continuous line is the u.v. absorbance $\left(\boldsymbol{A}_{\mathbf{2} 80}\right)$ of protein eluted from the column; the broken line represents the FPP synthase activity. Molecular-mass standards are (1) myoglobin (17000 Da), (2) ovalbumin (45000 Da), (3) IgG (158000 Da) and (4) thyroglobulin $(670000 \mathrm{Da})$. The arrow indicates the location of FPP synthase fusion protein.

\section{Molecular mass determination}

The molecular mass of the homogeneous FPP synthase fusion protein under non-denaturing conditions was estimated by chromatography on an h.p.l.c. gel-exclusion column (Bio-Sil SEC-250). A single symmetrical peak of activity corresponding to a molecular mass of $78-80 \mathrm{kDa}$ was seen (Fig. 4). subunit molecular mass was estimated by SDS/PAGE. The relative mobility of the FPP synthase fusion protein corresponded to a protein of $39-40 \mathrm{kDa}$, which is consistent with a dimeric structure for the protein. Since the human cDNA encodes a single subunit of FPP synthase, the functional enzyme is composed of two identical subunits.

The estimated molecular mass of the FPP synthase fusion protein was slightly larger than that of native human liver FPP synthase, previously determined to be $74000 \pm 1400 \mathrm{Da}$ (Barnard \& Popják, 1981). It is not at present known how many amino acids may be missing from the $5^{\prime}$ end of the human cDNA; however, a closely related rat liver cDNA encodes six additional amino acids at the $N$-terminus. Although our fusion protein contains the first six amino acids of $E$. coli $\beta$-galactosidase, this fragment is too small to account for the difference in molecular mass, and the results probably reflect the different chromatographic methods used by the two laboratories.

\section{Kinetic constants}

Michaelis constants for IPP and GPP were determined from initial velocities measured as described in the Materials and methods section. The data were fitted to eqn. (1) for a sequential mechanism using a non-linear regression analysis.

$$
v=\frac{V_{\text {max. }}[\mathrm{A}][\mathrm{B}]}{K_{\mathrm{I}}^{\mathrm{A}} K_{\mathrm{m}}^{\mathrm{B}}+K_{\mathrm{m}}^{\mathrm{B}}[\mathrm{A}]+K_{\mathrm{m}}^{\mathrm{A}}[\mathrm{B}]+[\mathrm{A}][\mathrm{B}]}
$$

where $v$ is the observed initial reaction rate, $V_{\text {max. }}$ is the maximum reaction velocity, [A] and [B] are the concentrations of the substrates binding to the enzyme, GPP and IPP respectively, $K_{\mathrm{I}}^{\mathrm{A}}$ is the dissociation constant of GPP, and $K_{\mathrm{m}}^{\mathrm{A}}$ and $K_{\mathrm{m}}^{\mathrm{B}}$ are the
Michaelis constants for A and B. Double-reciprocal plots (not shown) were similar to those reported for the avian liver enzyme (Laskovics et al., 1979). Although it is not possible to establish the order of binding for FPP synthase from a steady-state kinetic analysis (Laskovics et al., 1979), it is likely that the human liver and avian liver enzymes have similar mechanisms. In the latter case, an ordered addition of substrates, with GPP added first, was established by isotope-trapping experiments (Laskovics \& Poulter, 1981).

The nearly parallel plots lead to substantial uncertainties in values for $K_{\mathrm{m}}$. However, the $K_{\mathrm{m}}$ values for substrates A and B, $0.43 \pm 0.32 \mu \mathrm{M}$ and $0.55 \pm 0.17 \mu \mathrm{M}$ respectively, are similar to values reported by Barnard \& Popják (1981) for the human liver ( 0.44 and $0.94 \mu \mathrm{M}$ respectively) and by Reed \& Rilling (1976) and Laskovics et al. (1979) for avian liver (0.4 and $0.1 \mu \mathrm{M}$ respectively) FPP synthase. The $V_{\text {max. }}$ for the synthesis of FPP from these substrates was $1.08 \pm 0.24 \mu \mathrm{mol} / \mathrm{min}$ per mg. In addition, the hpt807 enzyme shows substrate inhibition by IPP at high ratios of IPP/GPP, analogous to behaviour reported for the avian liver FPP synthase.

\section{Enzyme activity}

The activity of purified fusion protein was measured in the presence of IPP and GPP, and compared with those of partially purified human liver FPP synthase. The FPP synthase activities of both enzymes were linear up to $10 \mathrm{~min}$ at $37^{\circ} \mathrm{C}$. No activity was observed in the absence of GPP.

The activities of both enzymes were also compared in the presence of bis-diphosphate inhibitor. The bis-diphosphate is an IPP-DMAPP bisubstrate analogue and is a potent inhibitor of avian liver FPP synthase (L. B. Perez \& C. D. Poulter, unpublished work). Although 3-methyl-6-methylene-oct-2-ene-1,8-diyl bis-diphosphate inhibited both enzymes, the $\mathrm{IC}_{50}$ (concn. giving $50 \%$ inhibition) was lower for the FPP synthase fusion protein than for the partially purified human liver enzyme $(4 \mu \mathrm{M}$ and $50 \mu \mathrm{M}$ respectively). When the assay with human liver FPP synthase was carried out in the presence of $5 \mathrm{mM}-\mathrm{KF}$, a phosphatase inhibitor, the $\mathrm{IC}_{50}$ for the bis-diphosphate inhibitor declined from $50 \mu \mathrm{M}$ to $23 \mu \mathrm{M}$. In addition, the $\mathrm{IC}_{50}$ was greater than $400 \mu \mathrm{M}$ in the absence of KF when a crude human extract (S-100 fraction) was used as the source of enzyme. These results suggest that the high $\mathrm{IC}_{50}$ observed with partially purified human liver FPP synthase most likely results from hydrolysis of the diphosphate moieties in the inhibitor by contaminating phosphatases. Saito \& Rilling (1979) have shown that the diphosphate moieties of both substrates are essential for tight binding to the enzyme. The bis-diphosphate inhibitor is susceptible to phosphatase hydrolysis, and loss of either diphosphate group should decrease its activity. Unfortunately, KF concentrations above $5 \mathrm{~mm}$ inhibited FPP synthase activity, and we were therefore unable to suppress phosphatase activity selectively in these assays. These results do not permit us to compare directly the extent of inhibition of the two enzymes by the bisubstrate analogue. However, our results demonstrate that a potent inhibitor of liver FPP synthase is also a potent inhibitor of the FPP synthase fusion protein.

As a group, prenyltransferases involved in 1'-4 condensation catalyse the addition of the isopentenyl moiety in IPP to allylic prenyl acceptors. Specificity is seen in the number of isoprene units added and the stereochemistry of the new trisubstituted double bonds. FPP synthase catalyses two trans additions to DMAPP (Poulter \& Rilling, 1981; Ogura et al., 1985), whereas a representative cis-prenyltransferase, dolichol diphosphate synthase, catalyses 13-18 cis additions to trans, trans-FPP (Adair et al., 1984). To date, relatively few details are known about the basis for specificity in these different enzymes. To determine if 
the recombinant FPP synthase had higher prenyltransferase activity (i.e. the ability to make isoprenes larger than $\mathrm{C}_{15}$ ), an assay for condensation with FPP was carried out by a modified procedure described previously (Adair et al., 1984; Adair \& Cafmeyer, 1987). Enzyme activity was measured by incorporation of $\left[{ }^{14} \mathrm{C}\right] \mathrm{IPP}$ into polyprenyl diphosphate products, with FPP as the allylic primer (Wellner \& Lucas, 1979). Enzyme activity was linear for up to $1 \mathrm{~h}$ in liver microsomal fractions which are known to contain higher prenyltransferase activity. However, a small amount was found in both human liver FPP synthase and FPP synthase fusion protein. Although the products from FPP have not been identified, geranylgeranyl diphosphate is a likely candidate (Reed \& Rilling, 1975).

In conclusion, the purification of recombinant FPP synthase fusion protein was accomplished by using two chromatographic steps. The homogeneous recombinant enzyme is virtually identical with the human liver FPP synthase in its physical and catalytic properties. The fusion protein can easily be purified in large quantities by this procedure; thus mechanistic, structural and inhibitor studies of the human FPP synthase are now possible.

We thank Dr. Herb G. Bull for enzyme kinetic analysis and Dr. Anthony Y. H. Lu for his suggestions in preparing this manuscript. We also thank Joan Kiliyanski for her help in typing this manuscript.

\section{REFERENCES}

Adair, W. L. \& Cafmeyer, N. (1987) Arch. Biochem. Biophys. 259, 589-596

Adair, W. L., Cafmeyer, N. \& Keller, R. K. (1984) J. Biol. Chem. 259, 4441-4446

Barnard, G. H. \& Popják, G. (1981) Biochim. Biophys. Acta 661, 87-99

Clarke, C. F., Tanaka, R. D., Svenson, K., Wamsley, M., Fogelman, A. M. \& Edwards, P. A. (1987) Mol. Cell. Biol. 7, 3138-3146

Coon, M. J., van der Hoeven, T. A., Dahl, S. B. \& Haugen, D. A. (1978) Methods Enzymol. 52C, 109-117

Eberhardt, N. L. \& Rilling, H. C. (1975) J. Biol. Chem. 250, 863-866
Faust, J. R., Brown, M. S. \& Goldstein, J. L. (1980) J. Biol. Chem. 255, 6546-6548

Green, T. R. \& West, C. A. (1974) Biochemistry 13, 4720-4729

Hancock, J. F., Magee, A. I., Childs, J. E. \& Marshall, C. J. (1989) Cell 57, 1167-1177

Holloway, P. W. \& Popják, G. (1967) Biochem. J. 104, 57-70

Ishii, K., Sagami, H. \& Ogura, K. (1986) Biochem. J. 233, 773-777

Laemmli, U. K. (1970) Nature (London) 227, 680-685

Laskovics, F. M. \& Poulter, C. D. (1981) Biochemistry 20, 1893-1901

Laskovics, F. M., Krafcik, J. M. \& Poulter, C. D. (1979) J. Biol. Chem. 254, 9458-9463

Light, D. R. \& Dennis, M. S. (1989) J. Biol. Chem. 264, 18589-18597

Lowry, O. H., Rosebrough, N. J., Farr, A. L. \& Randall, R. J. (1951) J. Biol. Chem. 193, 265-275

McGrath, R. (1977) in Bio-organic Chemistry (van Tamelin, E. E., ed.), vol. 1, pp. 231-257, Academic Press, New York

Momose, K. \& Rudney, H. (1972) J. Biol. Chem. 247, 3930-3940

Ogura, K., Nishino, T., Shinka, T. \& Seto, S. (1985) Methods Enzymol. 110, 167-170

Poulter, C. D. \& Rilling, H. C. (1978) Acc. Chem. Res. 11, 307-313

Poulter, C. D. \& Rilling, H. C. (1981) in Biosynthesis of Isoprenoid Compounds (Porter, J. W. \& Spurgeon, S. L., eds.), vol. 1, pp. 162-224, John Wiley and Sons, New York

Poulter, C. D., Mash, E. A., Argyle, J. C., Muscio, O. J. \& Rilling, H. C. (1979) J. Am. Chem. Soc. 101, 6761-6763

Reed, B. C. \& Rilling, H. C. (1975) Biochemistry 14, 50-54

Reed, B. C. \& Rilling, H. C. (1976) Biochemistry 15, 3739-3745

Rilling, H. C. (1985) Methods Enzymol. 110, 145-152

Rilling, H. C., Bruenger, E., Epstein, W. W. \& Kandutsch, A. A. (1989) Biochem. Biophys. Res. Commun. 163, 143-148

Sagami, H., Ogura, K. \& Seto, S. (1978) Biochem. Biophys. Res. Commun. 85, 572-578

Saito, A. \& Rilling, H. C. (1979) J. Biol. Chem. 254, 8511-8515

Schafer, W. R., Kim, R., Sterne, R., Thorner, J., Kim, S. H. \& Rine, J. (1989) Science 245, 379-385

Sheares, B. T., White, S. S., Molowa, D. T., Chan, K., Ding, V. D. H., Kroon, P. A., Bostedor, R. G. \& Karkas, J. D. (1989) Biochemistry 28, 8129-8135

Swank, R. \& Munkres, K. (1971) Anal. Biochem. 39, 462-477

Trumpower, B. L., Houser, R. M. \& Olson, R. E. (1974) J. Biol. Chem. 249, 3041-3048

Wellner, R. B. \& Lucas, J. J. (1979) FEBS Lett. 104, 379-383

Wong, T. K. \& Lennarz, W. J. (1982) J. Biol. Chem. 257, 6619-6624

Received 26 June 1990; accepted 8 October 1990 